\title{
ESTIMATION OF FOREST COVERAGE IN NORTHERN REGION OF MONGOLIA USING SENTINEL AND LANDSAT DATA
}

\author{
B. Norovsuren ${ }^{1,2,3, *}$, T. Renchin $^{1}$, B. Tseveen ${ }^{2}$, A. Yangiv ${ }^{4}$, T.Altanchimeg ${ }^{1}$ \\ ${ }^{1}$ NUM-ITC-UNESCO Laboratory for Space Science and Remote Sensing, National University of Mongolia, Ulaanbaatar, Mongolia \\ - bayan1225@gmail.com*; tsolmon@num.edu.mn \\ ${ }^{2}$ Dept. of Environment and Forest Engineering, National University of Mongolia, Ulaanbaatar, Mongolia - \\ batchuluun@num.edu.mn \\ ${ }^{3}$ Laboratory for Geo mineralization, Mongolian National University (MNU) - \\ n.bayanmunkh@mnun.edu.mn \\ ${ }^{4}$ Environmental Research, Information and Study Centre (ERISC) - ya_ariunzul@yahoo.com
}

\section{Commission V, WG V/7 \& Commission IV, WG IV/6}

KEY WORDS: Remote Sensing, Forest Index, Forest Cover, Sentinel, Management

\begin{abstract}
:
This paper aims to apply Forest Index (FI) and to determine forest coverage in the study area. The study area $\left(49^{0} 15^{\prime}\right.$ to $49^{\circ} 10^{\prime} \mathrm{N}$ and $104^{0} 05^{\prime}$ to $104^{0} 15^{\prime} \mathrm{E}$ ) is located in the northern region of Mongolia and consist of mixed forest. Larch forest (86.12\%) is dominating in the study area. The Sentinel-2 satellite data for the years 2015-2019 were used in the research. The land surface temperature (LST) was produced from Landsat-8 OL. FI methodology was applied for the Sentinel data in order to estimate larch forest coverage. The output map of forest coverage was compared with ground truth measurements and thematic map. The agreement between FI map and ground measurement was 85\%. LST from Landsat and FI from Sentinel were sampled in to same size. The relationship between LST (Landsat-8) and FI (Sentinel-2) was reasonable ( $\mathrm{R}=0.5)$. FI index and LST is applicable for different forest type in the region.
\end{abstract}

\section{INTRODUCTION}

\subsection{Background}

Forested areas, planted forests, bush and shrub stands, harvesting areas, the forested areas damaged by forest and steppe fire, pest insects and diseases, glades and the area extending to 100 meters beyond the outer edge of the forest, as well as seedlings and nursery areas to the land of forest fund (Government of Mongolia, 2012). Forest area belong to boreal zone in Mongolia. The northern boreal forests are part of the transitional zone between the Siberian taiga forest to the north and the grasslands to the south. These forests are mainly coniferous, mixed with some broadleaf trees (UN-REDD, 2017). Mixed forest is the basis for conducting research on various species of trees and bushes.

The regional or global scale, remote sensing techniques always offer an effective way for forest measurement and monitoring. Remote Sensing can be used to measure and monitor develop environmental policies and plans of the research areas (Enkhjargal et al., 2014). Nowadays many researches for forest cover mapping, forest type, forest degradation, fire of forest, inspected area uses active and passive remote sensing (Mitchell et al., 2017). In Mongolia, most research focused on using forest inventory statistics to estimate total forest area to further explore remote sensing or sources lacking image-based spatial information (Norovsuren et al., 2019) and small scale uncertainties still existed in some related researches. The main goal of this study was to map the change of forest area using satellite image data and the ground truth data.

The forest index (FI) is derived from three green, red and nearinfrared (NIR) bands and an FI image can be classified into forest and non-forest map with a threshold (Ye, Li, Chen, \& Zhang, 2014). Scatter plot of the spectral space NDVI is similar to that of the spectral space between LST and NDVI, by in-deep analysis (Yao, Qin, Zhu, \& Yang, 2008). In comparison with the latest Landsat OLI/TIRS, Sentinel-2 has a better spatial resolution, better spectral resolution in the near infrared region, but does not offer thermal data (Kaplan \& Avdan, 2017). The LST was produced from Landsat-8 OLI to better define forest coverage. Landsat-derived LST is also used for monitoring the forested areas, such as the correlation of LST with tree loss or the detection of changes in forest cover (Parastatidis et al., 2017; Rogan et al., 2013) (Parastatidis et al., 2017). It is possible to define the FI threshold by extracting the LST change. To extract forest cover from remotely sensed imagery, various methods have been proposed during the past decades. Some of these methods are based on supervised classification techniques to generate forest/non-forest classification aps, such as maximum likelihood (Bayarsaikhan et al., 2009), object-based classification and spectral index (Weih \& Riggan, 2010). These VI are effective to distinguish vegetation from other non-vegetation land covers (e.g. water and impervious surfaces), but difficult to distinguish forest from non-forest vegetation (Ye et al., 2014).

While remote sensing technology must help in providing information to satisfy the needs that forest managers have, remote sensing must be a cost-effective and easily understandable technology (Altangerel \& Udval, 2019). This research aims to apply FI and LST in order to improve forest estimation map. A combination between the forest taxation inventory, LST and the forest index were used in the research.

\subsection{Study area}

The study area is Bulgan province is situated in the northern part of Mongolia borders with Russian Federation. Bulgan province,

\footnotetext{
* Corresponding author
} 
is located in the taiga zone, forest steppe zone and steppe zone. Majestic high mountains of Bulgan, Buregkhangai and Dulaankhaan dominate in the northern part of the province. The north of the province is characterized by alpine forests, gradually blending in the arid steppe plains of the central Mongolian highland (Figure 1).
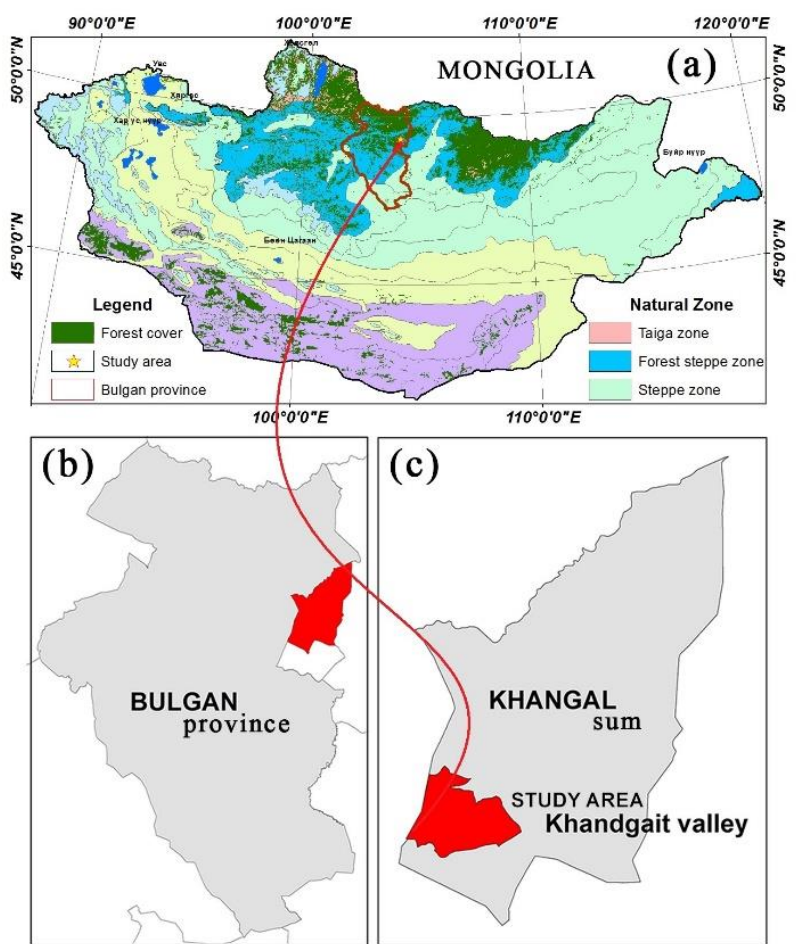

Figure 1. Location map (b) The distribution of natural zones in Mongolia and (b) Khangal soum in Bulgan province (c) the study area whit the red color

According to the Holdridge life zones system of bioclimatic classification Bulgan is situated in the boreal dry scrub biome (larch, birch and shrub) where larch is $86.12 \%$ and birch is $13.88 \%$. According to our survey, the forest in Khandgait valleys covers an area of 11540 hectares and its elevation is between $1260 \mathrm{~m}$ and $1570 \mathrm{~m}$ (Norovsuren et al., 2019). This area has a subarctic climate where the annual average temperature is -1.3 degrees Celsius (29.7 degrees Fahrenheit) and total annual precipitation averages is $278.4 \mathrm{~mm}$.

\section{DATASETS}

We used datasets; field data, FI data and Satellite Remote Sensing data in this research.

\subsection{Field Data}

The surveyed plots are located in areas where major disturbances, such as forest fire and clear cutting. The sampled stands differ for main type, leaf presence and type of field plots (size, shape, and number) (Laar, 2007). All ground data were collected during 2016-2019. In each plot, the following attributes were measured: diameter at breast $(\mathrm{DBH})$ of living and dead stems (diametric threshold $<5 \mathrm{~cm}$ ), species. The results of field measurements were also used for measurements of the previous survey and the Forest Research and Development Center (Yangiv et al., 2017). Some field measurements are shown in (Table 1).

\begin{tabular}{|c|c|c|c|c|c|c|}
\hline Id & $\begin{array}{l}900 M^{2} \\
\text { trees }\end{array}$ & $\begin{array}{c}\text { High } \\
\text { (m) }\end{array}$ & $\begin{array}{c}\text { Diameter } \\
(\mathrm{cm})\end{array}$ & $\begin{array}{l}\text { Coronary } \\
\text { diameter }\end{array}$ & $\begin{array}{c}\text { Tree } \\
\text { spacing }\end{array}$ & $\begin{array}{l}\text { Type } \\
\text { of tree }\end{array}$ \\
\hline$K-001$ & 0 & 1 & 0 & 0 & 0 & Shrub \\
\hline$K-002$ & 41 & 12 & 23 & 2.3 & 3 & Larix \\
\hline$K-003$ & 111 & 6.7 & 9 & 2.1 & 1.2 & Larix \\
\hline$K-004$ & 29 & 17 & 33 & 4 & 8 & Birch \\
\hline$K-005$ & 98 & 15 & 16 & 2.9 & 2 & Larix \\
\hline$K-006$ & 2 & 19 & 28 & 4 & 6.2 & Larix \\
\hline$K-007$ & 168 & 15 & 9 & 2.9 & 1.7 & Larix \\
\hline$K-008$ & 47 & & 15.5 & 3.1 & 4.5 & Larix \\
\hline$K-009$ & 12 & 11 & 34.3 & 4.48 & 2.5 & Larix \\
\hline$K-010$ & 116 & 17 & 24.8 & 3.8 & 3.6 & Larix \\
\hline$K-011$ & 95 & 9.4 & 12.5 & 2.6 & 5 & Larix \\
\hline$K-012$ & 75 & 11 & 21 & 1.15 & 3.1 & Larix \\
\hline$K-013$ & 85 & 12 & 23 & 3.7 & 4 & Larix \\
\hline$K-014$ & 87 & 11 & 15.5 & 3 & 7.2 & Larix \\
\hline$K-015$ & 85 & 7.1 & 11 & 2.1 & 3.1 & Larix \\
\hline$K-016$ & 45 & 16 & 38 & 4.3 & 7 & Larix \\
\hline$K-017$ & 52 & 24 & 35 & 5 & 5 & Larix \\
\hline$K-018$ & 75 & 11 & 15.5 & 2 & 3.5 & Birch \\
\hline$K-019$ & 29 & 19 & 29.8 & 2.44 & 3.8 & Larix \\
\hline$K-020$ & 154 & 12 & 11 & 2.5 & 2.6 & Birch \\
\hline$K-021$ & 29 & 20 & 35 & 4.27 & 7 & Larix \\
\hline$K-022$ & 122 & 11 & 12.6 & 4 & 1.2 & Birch \\
\hline$K-023$ & 87 & 18 & 28.1 & 2.5 & 2.3 & Larix \\
\hline$K-024$ & 26 & 7.5 & 11.5 & 2 & 5.8 & Larix \\
\hline$K-025$ & 24 & 16 & 22.5 & 3.4 & 8 & Larix \\
\hline$K-026$ & 0 & 1 & 0 & 0 & 0.8 & Shrub \\
\hline$K-027$ & 0 & 0.2 & 0 & 0 & 0.5 & Shrub \\
\hline$K-028$ & 0 & 0.2 & 0 & 0 & 0.5 & Shrub \\
\hline$K-029$ & 7 & 18 & 28 & 4.8 & 2.5 & Larix \\
\hline$K-030$ & 21 & 20 & 31.7 & 4 & 5 & Larix \\
\hline$K-031$ & 34 & 16 & 3.3 & 3.9 & 5 & Larix \\
\hline$K-032$ & 6 & 20 & 26.5 & 5.5 & 15 & Larix \\
\hline$K-033$ & 26 & 0 & 23.5 & 0 & 6 & Larix \\
\hline$K-034$ & 24 & 6.9 & 14.5 & 1.2 & 5 & Larix \\
\hline$K-035$ & 92 & 2.2 & 1.5 & 0.69 & 1 & Larix \\
\hline$K-036$ & 120 & 10 & 13 & 2.5 & 1.5 & Birch \\
\hline$K-037$ & 0 & 0 & 0 & 0 & 0.2 & Shrub \\
\hline$K-038$ & 83 & 8.7 & 9.2 & 2.3 & 3.6 & Birch \\
\hline
\end{tabular}

Table 1. Field measure data (2016-2019)

\subsection{Forest Inventory Data}

The systematical national forest inventory (NFI) has been conducted nearly every ten years since the late 1956 and the last national forest inventory was conducted for the period 2013 (FDRE, 2018). The statistics of the national forest inventory in Mongolia are based on large numbers of field plots and are the most important data sources for research on forest.

\subsection{Satellite Remote Sensing Data}

The multispectral bands visible Green $(560 \mathrm{~nm})$, Red $(665 \mathrm{~nm})$, and Near-Infrared (NIR) (842 nm) over years 2015-2019 were used in this research (Table 2). The satellite images were downloaded based on survey time, geographical extent and environmental conditions. Landsat 8 Operational Land Imager (OLI) image (September 2018, path 133, row 26) was downloaded from the USGS earth resource observation and science center (EROS) (http://glovis.usgs.gov/).

\begin{tabular}{cccc}
\hline & $\begin{array}{c}\text { Multispectral } \\
\text { band (s) }\end{array}$ & $\begin{array}{c}\text { Wavelength } \\
(\boldsymbol{\mu m})\end{array}$ & $\begin{array}{c}\text { Time } \\
\text { Period }\end{array}$ \\
\hline \multirow{3}{*}{ Sentinel-2 } & Band 3 & $0.537-0.582$ & \multirow{2}{*}{$2015-$} \\
& Band 4 & $0.646-0.685$ & 2019 \\
\cline { 2 - 3 } & Band 8 & $0.767-0.908$ & \\
\hline Landsat-8 & Band 10 & $10.60-11.19$ & 2018 \\
\cline { 2 - 3 } & Band 11 & $11.50-12.51$ & \\
\hline
\end{tabular}

Table 2. Sentinel-2 and Landsat-8 NIR, TIRS bands: wavelengths, and time period covered. 


\section{METHODOLOGY}

We used Remote sensing methodology for the middle-resolution satellite data. Assessment processed with the layer of the data such as Forest taxation data of the FRDC, Google Earth Pro and Bing map used SNAP and GIS software's. We used forest index for the Sentinel satellite data when we define forest cover area of study area. Following schema shows methodology step by step (Figure 2).

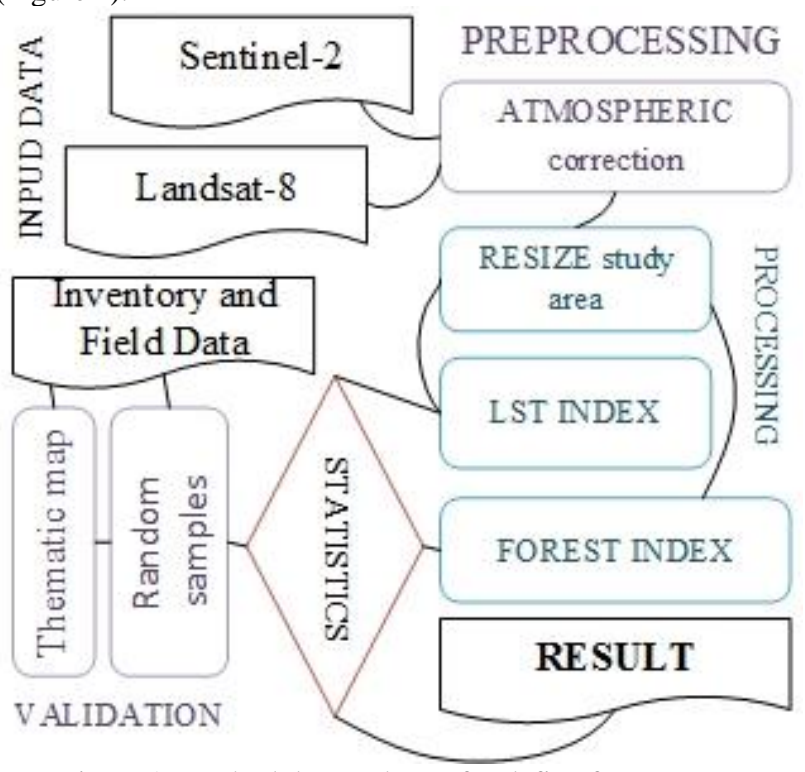

Figure 2. Methodology schema for define forest cover

\subsection{Data pre-processing}

In the current study, the Sentinel-2 data were pre-processed using the SNAP v. 4.0.0. (Sentinel Application Platform) developed by ESA (European Space Agency). This software incorporates the plugin "Sen2Cor"(Belgiu \& Csillik, 2018). This plugin performs an atmospheric correction of Top-OfAtmosphere (TOA) Level 1C input data. Sen2Cor creates Bottom-Of-Atmosphere, optionally terrain and cirrus corrected reflectance images; additional, Aerosol Optical Thickness-, Water Vapor-, Scene Classification Maps and Quality Indicators for cloud and snow probabilities (Clerici et al., 2017). The Sentinel-2 Level $1 \mathrm{C}$ at the top of the atmosphere (TOA) reflectance data was then processed to Level-2A using ESA's Sen2Cor algorithm to obtain the bottom of the atmosphere (BOA) reflectance images using (http://step.esa.int/main/thirdparty-plugins-2/sen2cor/). Selection of the proper resampling technique for registration of multidate Landsat imagery can be important to digital classification accuracy in mountainous forest areas (Mitchell et al., 2017). Resampling is usually done for the digitizing the pixel values from the existing cell values (Roy et al., 2016).

Resampling was done between LST from Landsat-8 and FI from Sentinel-2 satellite.

\subsection{Estimation Algorithm for forest cover}

Cohen (1991) suggests that the first true vegetation index was the Simple Ratio (SR), which is the ratio of red reflected radiant flux ( and McVey (1968) as:

$$
R V I=N I R / R E D
$$

Vegetation indexes created for define vegetation and nonvegetation area not for forest and non-forested area. That is why it is difficult to differentiate similar area between forest and nonforest vegetation area. The reason of that we picked up Forest Index for our research. To make the process of forest cover mapping simple and rapid, a simple spectral index called forest index (FI) was proposed to highlight the forest land cover by a threshold in Landsat scenes. (Ye et al., 2014)

$$
F I=\left(\frac{\rho_{N I R}-\rho_{\text {red }}-L}{\rho_{N I R}+\rho_{\text {red }}}\right)\left(\frac{C_{1}-\rho_{N I R}}{C_{2}+\rho_{\text {green }}}\right)
$$

where

$$
\begin{aligned}
& L=0.01 \\
& C_{1}=1 \\
& C_{2}=0.1
\end{aligned}
$$

The parameter $\mathrm{L}$ is a very small value and the introduction of which can effectively lower the NDVI of water while has little impact on the NDVI of vegetation. $\mathrm{C}_{1}$ and $\mathrm{C}_{2}$ are empirical parameters used to scale the function. Thus, the range of the FI is from minus infinity to 7. FI gives a positive value on forested area and vice versa negative value on the non-forested area.

Single channel (SC) is a commonly-used approach to estimate LST from the Landsat thermal infrared observations (Ndossi \& Avdan, 2016). Among Landsat 5, 7 and 8, only Landsat 8 carries two thermal bands (Parastatidis et al., 2017), therefore the SC approach is used in this study for consistency. The LST was calculated using Equation (3) by (Natsagdorj et al., 2019).

$$
L S T=\left(B T+w * \frac{B T}{p}\right) * \ln (e)
$$

where $B T$ is the satellite brightness temperature $(\mathrm{K})$; $w$ is the wavelength of emitted radiance $(11.5 \mu \mathrm{m})$; $p=\mathrm{h}^{*} \mathrm{c} / \mathrm{s}\left(1.438 * 10^{\wedge}-2 \mathrm{~m} \mathrm{~K}\right)$,

$h$ is the Plank's constant $\left(6.626^{*} 10^{\wedge}-34 \mathrm{Js}\right)$; $s$ is the Boltzman constant $\left(1.38^{*} 10^{\wedge}-23 \mathrm{~J} / \mathrm{K}\right)$, $c$ is the velocity of light $\left(2.998^{*} 10^{\wedge} 8 \mathrm{~m} / \mathrm{s}\right)$; $e=0.004 * P v+0.986$, $P v=\left(\mathrm{NDVI}-\mathrm{NDVI}_{\min } / \mathrm{NDVI}_{\max }-\mathrm{NDVI}_{\min }\right)^{2}$ is the proportion of vegetation.

Resampling is the technique of manipulating a digital image and transforming it into another form. (Baboo \& Devi, 2010) This technique is used extensively in image processing for all applications, including medical, industrial and of course in remote sensing. Calculation of the new pixel value is performed by the weight of the four surrounding pixels. The bilinear interpolation is performed by the following (Equation 4).

$$
\begin{gathered}
P(x, y)=P(1,1) *(1-d) *(1-d)+P(1,2) * d *(1-d) \\
+P(1,2) * d *(1-d)+P(2,2) * d * d
\end{gathered}
$$

The equation 2 was applied for estimation forest cover using sentinel data analysis (Figure 3).

\section{ANALYSIS}

FI defined forest cover over years 2015-2019 using Sentinel-2. Figure 3 shows detailed information on NFI data. 


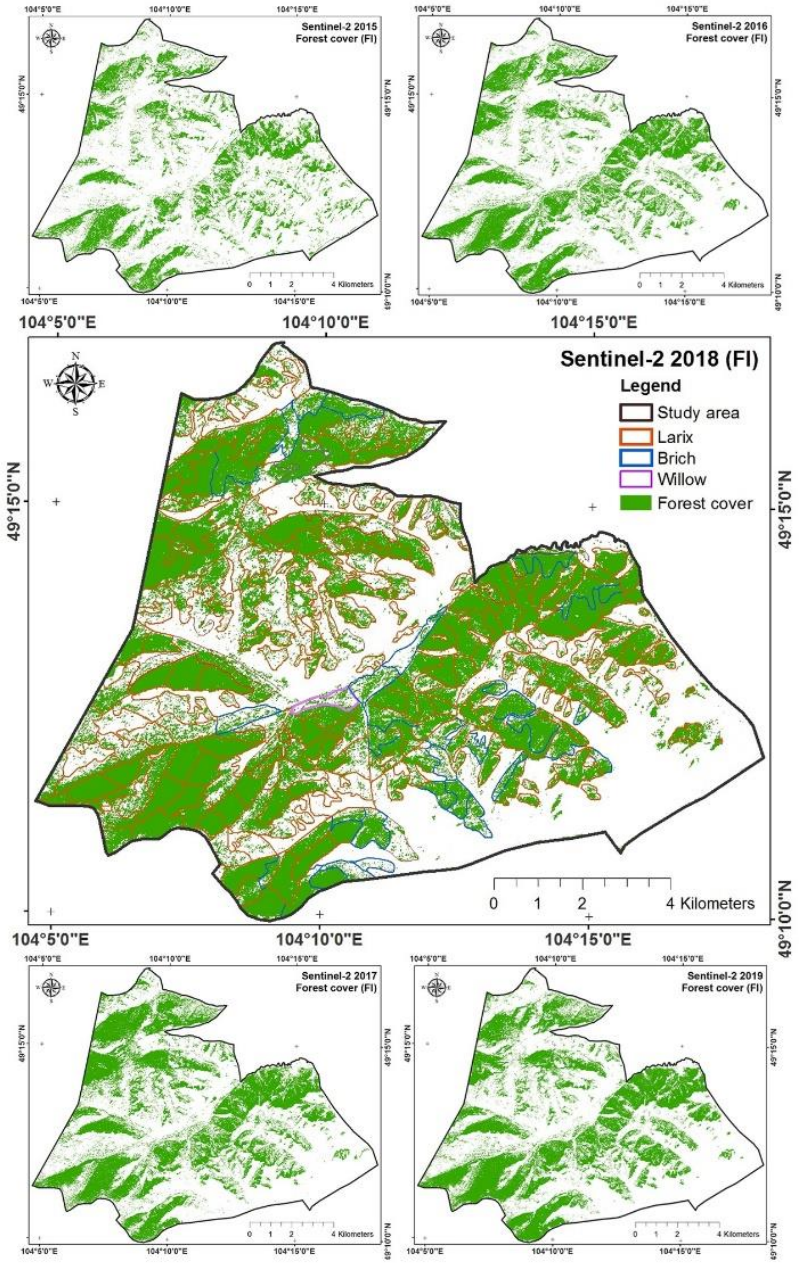

Figure 3. forest cover map 2015 to 2019 for FI whit NFI

However, some forest areas were also detected outside the NFI area suggesting that the boreal forest area for study area could be beyond the defined premises of the NFI.

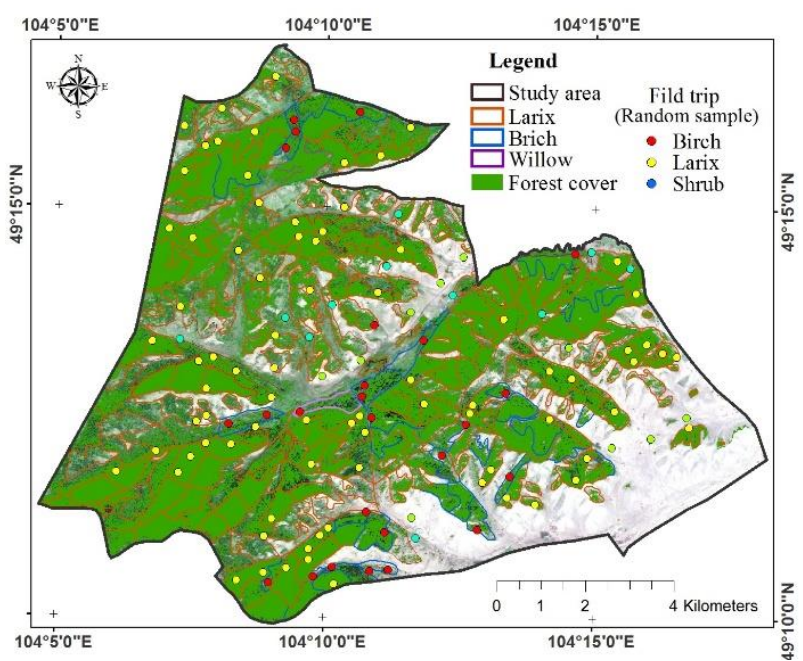

Figure 4. Field trip measured and forest cover validation map

Pixels labeled as forest in the map were all collected to make up the forest samples, and pixels labeled as NFV in the same map were all collected to make up the NFV samples.

Study area statistics are provided in (Table 3). The defined NFI area cover $15 \%$ of study area. In total the study area is covered by about 6434.4 hectares of boreal forest considering the $10 \mathrm{~m}^{2}$.
Body 2018

Area in ha

Study area

NFI

Forest cover

Non forest cover

11540

8184.7

6434.4

6905.6

Table 3. National forest inventory NFI and forest cover

For the validation the output map FI (figure 3) was compared with NFI data using confusion matrix (Table 4). There is a good agreement with forest inventory data which is $85 \%$.

\begin{tabular}{|c|c|c|c|c|}
\hline \multirow{2}{*}{$\gtrsim$} & \multicolumn{4}{|c|}{ National forest inventory } \\
\hline & & Forest & Non-Forest & $\sum$ \\
\hline \multirow{4}{*}{ 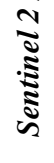 } & Forest & 1286 & 695 & 1981 \\
\hline & Non-Forest & 819 & 1431 & 2250 \\
\hline & $\sum$ & 2105 & 2126 & 4231 \\
\hline & Overall Acc & & & $85 \%$ \\
\hline
\end{tabular}

Table 4. Confusion matrix and accuracy estimates

Next, we applied LST for Landsat data. After that we made resampling LST FI from Sentinel-2 (Figure 5).

Finally, we found and the relationship between LST and FI which is reasonable (Figure 6).

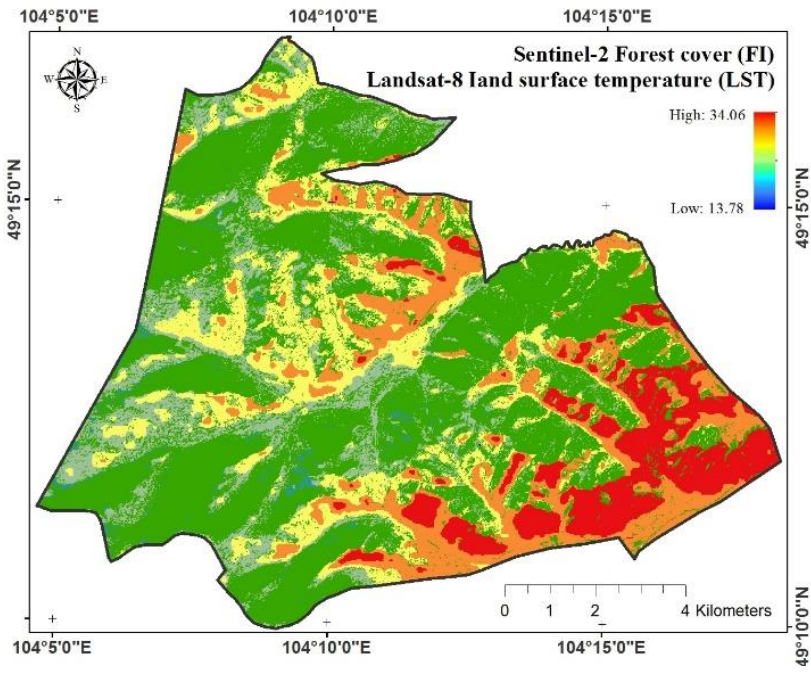

Figure 5. Field trip measured and forest cover validation map

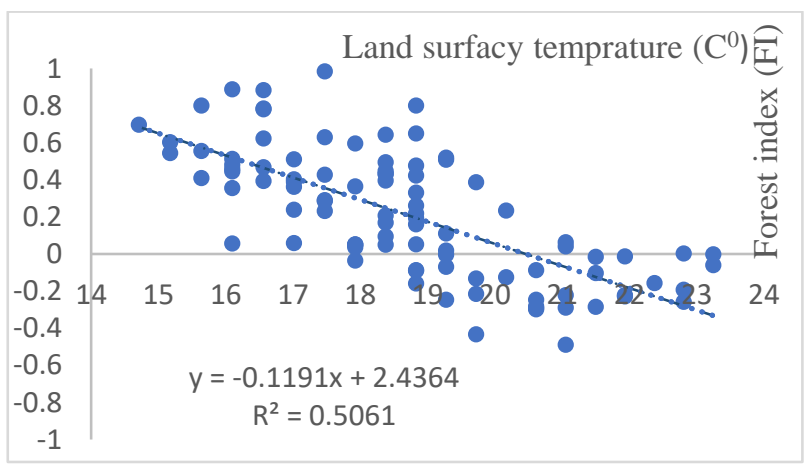

Figure 6. Relationship of forest index threshold and LST

\section{CONCLUSION AND RESULT}

FI map was overlaid and compared on Inventory map. The validation result is reasonable (Table 4). These results indicate that the FI can effectively highlight forest cover. Advantage of using FI allow us to monitor forest for every 5 years and compare 
with NFI data. FI can also analyse seasonal change for different forest in the region. Overall, the research indicates that modern RS techniques and technologies are reliable tools for forest monitoring and management.

\section{ACKNOWLEDGEMENTS}

This research was partially supported by Asian Research Centre (ARC), Mongolia and Korea Foundation for Advanced studies and Mongolian Geospatial Association. The authors would like to gratitude the "Forest Research and Development Centre" in Mongolia and "Khanbuyan" community for their kind support. Authors are thankful for SENTINEL DATA CENTER for providing data.

\section{REFERENCES}

Altangerel, M. \& Udval, B. (2019). Pixel-based Classification of Forest Area using Multi-source Satellite Images in Central Mongolia Pixel-based Classification of Forest Area using Multisource Satellite Images in Central Mongolia. (June).

Baboo, D. S. S., \& Devi, M. R. (2010). An Analysis of Different Resampling Methods in Coimbatore, District. Global Journal of Computer Science and Technology, 10(15), 61-66. Retrieved from http://globaljournals.org/GJCST_Volume10/10-AnAnalysis-of-Different-Resampling-Methods-in-Coimbatore-

District.pdf

Bayarsaikhan, U., Boldgiv, B., Kim, K. R., Park, K. A., \& Lee, D. (2009). Change detection and classification of land cover at Hustai National Park in Mongolia. International Journal of Applied Earth Observation and Geoinformation, 11(4), 273-280. https://doi.org/10.1016/j.jag.2009.03.004

Belgiu, M., \& Csillik, O. (2018). Remote Sensing of Environment Sentinel-2 cropland mapping using pixel-based and object-based time- weighted dynamic time warping analysis. Remote Sensing of Environment, 204(October 2017), 509-523. https://doi.org/10.1016/j.rse.2017.10.005

Clerici, N., Valbuena Calderón, C. A., \& Posada, J. M. (2017). Fusion of sentinel-1a and sentinel-2A data for land cover mapping: A case study in the lower Magdalena region, Colombia. $\begin{array}{llll}\text { Journal of } & \text { Maps, 13(2), }\end{array}$ https://doi.org/10.1080/17445647.2017.1372316

Enkhjargal, D., Amarsaikhan, D., Battsengel, V., Bat-Erdene, T., Sod-Erdene, J., \& Tsogzol, G. (2014). Applications of multitemporal optical images for forest resources study in Mongolia. 35th Asian Conference on Remote Sensing 2014, ACRS 2014: Sensing for Reintegration of Societies, (October).

FDRE. (2018). Mongolia's Forest Reference Level submission to the UNFCCC. https://doi.org/10.1299/kikaib.67.990

Government of Mongolia. (2012). Mongolian Law on Forest. 42. Kaplan, G., \& Avdan, U. (2017). MAPPING and MONITORING WETLANDS USING SENTINEL-2 SATELLITE IMAGERY. ISPRS Annals of the Photogrammetry, Remote Sensing and Spatial Information Sciences, 4(4W4), 271277. https://doi.org/10.5194/isprs-annals-IV-4-W4-271-2017

Laar, A. van. (2007). African, American and European Trajectories of Modernity. In K. von Gadow (Ed.), Published by Springer, P.O. Box 17, 3300 AA Dordrecht, The Netherlands. Retrieved from http://www2.ca.uky.edu/forestry/for250/Forest
Mensuration book.pdf

Mitchell, A. L., Rosenquist, A., \& Mora, B. (2017). Current remote sensing approaches to monitoring forest degradation in support of countries measurement, reporting and verification (MRV) systems for REDD+. Carbon Balance and Management, 12(1). https://doi.org/10.1186/s13021-017-0078-9

Natsagdorj, E., Renchin, T., De Maeyer, P., Dari, C., \& Tseveen, B. (2019). Long-term soil moisture content estimation using satellite and climate data in agricultural area of Mongolia. Geocarto International, $34(7), \quad 722-734$. https://doi.org/10.1080/10106049.2018.1434686

Ndossi, M. I., \& Avdan, U. (2016). Application of open source coding technologies in the production of Land Surface Temperature (LST) maps from Landsat: A PyQGIS plugin. Remote Sensing, 8(5). https://doi.org/10.3390/rs8050413

Norovsuren, B., Renchin, T., Tseveen, B., Mart, Z., \& Enkhjargal, N. (2019). The approach of above ground biomass estimation. International Journal of Science, Environment and Technology, 8(5), 1080-1086.

Norovsuren, B., Tseveen, B., Batomunkuev, V., \& Renchin, T. (2019). Estimation for forest biomass and coverage using Satellite data in small scale area, Mongolia. IOP Conference Series: Earth and Environmental Science, 320, 012019. https://doi.org/10.1088/1755-1315/320/1/012019

Parastatidis, D., Mitraka, Z., Chrysoulakis, N., \& Abrams, M. (2017). Online global land surface temperature estimation from landsat. Remote Sensing, 9(12), 1-16. https://doi.org/10.3390/rs9121208

Rogan, J., Ziemer, M., Martin, D., Ratick, S., Cuba, N., \& DeLauer, V. (2013). The impact of tree cover loss on land surface temperature: A case study of central Massachusetts using Landsat Thematic Mapper thermal data. Applied Geography, 45, 49-57. https://doi.org/10.1016/j.apgeog.2013.07.004

Roy, D. P., Li, J., Zhang, H. K., \& Yan, L. (2016). Best practices for the reprojection and resampling of Sentinel-2 Multi Spectral Instrument Level 1C data. Remote Sensing Letters, 7(11), 10231032. https://doi.org/10.1080/2150704X.2016.1212419

UN-REDD Mongolia National Programme. (2017). preliminary Assessment of the Drivers of Forest Change in Mongolia.

Weih, R. C., \& Riggan, N. D. (2010). Object-based classification vs. pixel-based classification: Comparitive importance of multiresolution imagery. The International Archives of the Photogrammetry, Remote Sensing and Spatial Information Sciences, XXXVIII, 1-6.

Yangiv, A. (2017). Monitoring Forest Cover Change in Mongolia with Participatory Approach. Retrieved from http://apfnet.cn/en/uploads/file/20171113/1510562496246141.p df

Yao, Y., Qin, Q., Zhu, L., \& Yang, N. (2008). Relating surface Albedo and vegetation index with surface dryness using Landsat ETM+ imagery. International Geoscience and Remote Sensing Symposium (IGARSS), https://doi.org/10.1109/IGARSS.2008.4778856

Ye, W., Li, X., Chen, X., \& Zhang, G. (2014). A spectral index 
for highlighting forest cover from remotely sensed imagery. Land Surface Remote Sensing II, 9260(March 2016), 92601L. https://doi.org/10.1117/12.2068775 